\title{
Public Debt and Sustainable National Development in Nigeria: Analysis of Fundamental Issues
}

\author{
Remi C. Okeke ${ }^{1, a^{*}}$, Adeline N. Idike ${ }^{1, b}$ \\ ${ }^{1}$ Department of Public Administration and Local Government, University of Nigeria, \\ Nsukka, Enugu State, Nigeria \\ aremiokeke@gmail.com, bojeleogbo@yahoo.com.
}

Keywords: Public debt, sustainable national development, Nigeria, fundamental issues

\begin{abstract}
This study raises some fundamental issues in the relationship between public debt and sustainable national development in Nigeria. The work is significant in highlighting the position of public debt in the subject area of public administration. The study finds a very weak linkage between public debt and sustainable national development in the Nigerian state. The theoretical framework of the investigation is the bureaucratic theory. The work finds that the bureaucracy is as guilty as the politician in the country, in the transmutation of public debt into a brand of national bazaar. It is finally recommended in the paper that taxation-increases be adopted as alternative to public debt, in ensuring that the current generation of the country's citizens, in meeting their immediate needs do not invariably endanger the capacity of future generations in the same regards.
\end{abstract}

\section{Introduction}

Before the 20th century, the accumulation of government debt was in general slow and occurred mainly in relation to wars [1]. In contemporary times however, government debt (public debt) is integral to the orthodoxy in public administration. According to some scholars [2], the origin of the gloomy Nigerian debt situation can be traced back to the late 1970s when there was the need to finance the widening deficit gap created by profligate spending. This marked the beginning of the end of the oil boom era, which was characterized by falling foreign exchange earnings, and rising fiscal deficits and external borrowing [2]. The era of the oil boom is seemingly, finally ending. Consequently, the relationship between public debt and sustainable national development is at the center of the concerns of this study. Another problem of the study strictly borders on the progress of national development in Nigeria. In the bid to augment the available domestic resources, successive governments in the country, have embarked on the acquisition of humongous sums of foreign debts to finance different national development plans [3]. How have these debts influenced sustainable national development?

Furthermore, the motivation for the study arose from the development that the Nigerian central government incurs a public debt of $\mathrm{N} 600$ billion on monthly bases to make up for the shortfall in workers' salaries [4]. This public administration challenge was also coming at a time that the Chinese Government was offering their Nigerian counterparts \$6billion loan for infrastructure development [5]. And according to trading economics [6], external debt in Nigeria increased to 10718.43 USD million in the fourth quarter of 2015, from 10617.35 USD million in the third quarter of 2015. External debt in Nigeria averaged 6375.33 USD million from 2008 until 2015, reaching an all time high of 10718.43 USD million in the fourth quarter of 2015 and a record low of 3627.50 USD million in the first quarter of 2009.

The central research question of this study therefore becomes: what has been the relationship between public debt and sustainable national development in Nigeria? Invariably, the objective of the study is to ascertain the nature of the relationship between public debt and sustainable national development in Nigeria.

It is instructive to state in clear terms that the study is conducted from the standpoint of public administration. It has accordingly; purposively avoided the analytical imperatives and trajectories 
that may tend to present the paper as an economics engagement. The study is accordingly significant in highlighting that public debt is also a subject matter of public administration. The tendency in extant literature has been to mainly engage in public debt research in the specific context of economics. The study has utilized the bureaucratic theory as framework of analysis and the critical mode of research as methodology.

\section{Theoretical Framework}

The theoretical framework of the study is the bureaucratic theory. According to Izueke [7] this theory came from the work of Max Weber (1864-1920). Weber described an ideal-type of organization (bureaucracy) as the most rational known means of achieving efficiency. He noted that an ideal type of organization is based on legal-rational authority. He believes that efficiency is achievable through the creation of tasks, a clearly defined hierarchy of authority, impersonality and detailed rules and regulations [7]. According to Celik and Dogan [8], the bureaucracy model of management was put forward by Weber and forms a part of Classic Management Theory. It introduces the idea that duties should be regulated to form a hierarchic system. In every step of the hierarchy, pre-determined law, method and administrative regulations determine authority and duties formally. Specialized staff members carry out labors being distinguished to parts, in accordance with determined rules and standards. Processes and communication are done in written form; workers obey directives, as they are based on legal authority [8].

Citing Akın [9], Celik and Dogan [8] say that again, according to Weber, the legal structure of contemporary state is licit in humans' esteem. This lawfulness thus covers social lawfulness beyond legal lawfulness. In order to speak of a contemporary state therefore and speak of administrative and legal rules, the compulsive power of an administrative organization and legal government must be observed in a politic society. Hence, when considered from this point, it is seen that Weber's approach to management is effective in all public institutions and associations, especially in forming the structures of a state [8,9]. Hence, Weber believes that adherence to the features of bureaucracy stated above would create a predictable, and enduring, efficient and organized structure [7].

The organizational origins of bureaucracy have since been transplanted to the organization of nation-states. Consequently, there are bureaucracies in nation-states. Implicit in the bureaucratic theory therefore is the assumption of expertise in functional organizations and the national bureaucracies. Thus, in applying the bureaucratic theory to this study, the extent to which this assumed expertise has related with public debt and sustainable national development in the Nigerian state has been examined.

\section{Conceptual Highlights}

\section{Public Debt}

Debt is created by the act of borrowing [10]. Public debts are accordingly depictable as government's borrowings. Differently stated, it is an amount of money owed by the government to institutions, government agencies and other bodies' resident in or outside the country [11]. However, conceptualizing public debt is not a highly straightforward matter. Normally, posits Bhatia [12], the government of a country has a large variety of debt obligations. Therefore, public debt may be defined in several different ways covering their alternative combinations and to suit the purpose of the definition. Thus at one extreme, it may include all financial liabilities of a government (including its currency) while at the other extreme, it may include only a few of them [12].

Accordingly, a clear-cut standard has to be taken regarding inter-governmental obligations like loans from the Central Government to the States. Similarly, a decision is required as to whether the Central Bank of the country is to be considered a part of the government or not, for estimating 
the volume and composition of public debt...We find that in most countries public debt has registered a continuous upward trend during the last few decades [12]. However, the critical issue (in this study) is the nature of usage of the accrued funds.

Modigliani [13] in Checherita and Rother [1] argued that the national debt (public debt) is a burden for next generations, which comes in the form of a reduced flow of income from a lower stock of private capital. This raises the issue of sustainable development. There is also the issue of "debt overhang", coined by Krugman [14], which refers to a situation in which a country's expected repayment ability on external debt falls below the contractual value of debt involved [1]. These scenarios create immense challenges for sustainable development in a country.

\section{Sustainable National Development}

Embedded in the concept of sustainable national development is the separable issue of sustainable development. To properly conceptualize the former therefore, the latter has to be accorded adequate attention. But sustainable development is among the social science concepts that are prone to variegated interpretations. However, according to Emas [15], although many definitions abound, the most often used definition of sustainable development is that proposed by the Brundtland Commission (named after the Commission's Chairman). In 1987, the Brundtland Commission published its report, Our Common Future, in attempt to link the issues of economic development and environmental stability. In doing so, this report provided the often-cited definition of sustainable development as the development that meets the needs of the present without compromising the ability of future generations to meet their own needs $[15,16]$.

Kutay and Tektüfekçi [17] further highlight that the concept of sustainable development, from 1970's to the present has evolved into definitions of three pillars of sustainability; social, economic and environmental, which are interrelated and complementary According to Kutay and Tektüfekçi, who cited other scholars [18], the International Union for the Conservation of Natural Resources (IUCN) introduced the term "sustainability", as an international issue, with the book The World Conservation Strategy in 1980. And since that date, the term began to be used with increased frequency and its economic, social and environmental dimensions were debated as well as its importance in the search for a new form of development [17].

In the public debt context of this study, the Brundtland Commission's conceptualization suffices. Then, if public debt meets the needs of the borrowing generations, what guarantees are there to ensure that such current debts do not impair the ability of future generations to meet their own needs? In the dimension of national development therefore, sustainable national development becomes the strand of national processes that engenders the development that fulfills these two conditions of intergenerational equity.

\section{Analysis of Fundamental Issues}

A particularly fundamental issue of interest in this work is the role of the bureaucracy in the public debt chain of the Nigerian case study. The bureaucracy is essentially at the center of the aggregation and presentation of public loan requests anywhere. The bureaucrats are also located at the middle of the accessing of related funds. In the implementation of the projects for which public debts are incurred, the bureaucracy is also a central organ of government's business. Therefore, the fundamental issues in the relationship between public debt and sustainable national development in Nigeria touch upon the role of the bureaucracy. Is public debt leading to sustainable national development in the country? If the response is in the negative, what has been the role of the bureaucracy?

Indeed, the bureaucracy is involved at the national and sub-national levels of the public debt scenario in Nigeria. The civil servants are usually there at every stage of the process. Tables 1-3 below show the debt profiles of the country as negotiated and obtained by the national and subnational governments. Table 1 shows the external debt stock of the Federal and States' governments as at 31 December 2015. 
Table 1: Nigerian States and Federal Governments' External Debt Stock as at 31st December, 2015 (Provisional) (in US Dollars)

\begin{tabular}{|c|c|c|c|c|c|}
\hline $\mathbf{S} / \mathbf{N}$ & $\begin{array}{l}\text { States and } \\
\text { FGN }\end{array}$ & Multilateral (\$) & $\begin{array}{c}\text { Bilateral/AFD } \\
\text { (\$) }\end{array}$ & $\begin{array}{l}\text { Bilateral(CHINA } \\
\text { EXIM BANK), } \\
\text { JICA, INDIA, } \\
\text { KFW and } \\
\text { Eurobonds (\$) }\end{array}$ & Total $(\$)$ \\
\hline 1 & Abia & $41,502,309.09$ & - & - & $41,502,309.09$ \\
\hline 2 & Adamawa & $42,556,440.81$ & $6,500,000.00$ & - & $49,056,440.81$ \\
\hline 3 & Akwa Ibom & $52,717,441.23$ & - & - & $52,717,441.23$ \\
\hline 4 & Anambra & $60,781,525.58$ & - & - & $60,781,525.58$ \\
\hline 5 & Bauchi & $85,335,689.10$ & - & - & $85,335,689.10$ \\
\hline 6 & Bayelsa & $37,602,856.36$ & - & - & $37,602,856.36$ \\
\hline 7 & Benue & $35,700,600.77$ & - & - & $35,700,600.77$ \\
\hline 8 & Borno & $23,189,858.24$ & - & - & $23,189,858.24$ \\
\hline 9 & Cross River & $116,403,069.67$ & $20,000,000.00$ & - & $136,403,069.67$ \\
\hline 10 & Delta & $38,792,421.97$ & - & - & $38,792,421.97$ \\
\hline 11 & Ebonyi & $47,166,600.06$ & - & - & $47,166,600.06$ \\
\hline 12 & Edo & $168,186,197.48$ & - & - & $168,186,197.48$ \\
\hline 13 & Ekiti & $54,982,558.30$ & - & - & $54,982,558.30$ \\
\hline 14 & Enugu & $65,328,840.62$ & $6,500,000.00$ & - & $71,828,840.62$ \\
\hline 15 & Gombe & $39,822,769.29$ & - & - & $39,822,769, .29$ \\
\hline 16 & Imo & $59,163,843.12$ & - & - & $59,163,843, .12$ \\
\hline 17 & Jigawa & $34,085,704.85$ & - & - & $34,085,704.85$ \\
\hline 18 & Kaduna & $226,368,167.93$ & - & - & $226,368,167.93$ \\
\hline 19 & Kano & $57,612,298.94$ & - & - & $57,612,298.94$ \\
\hline 20 & Katsina & $72,153,818.01$ & - & - & $72,153,818.01$ \\
\hline 21 & Kebbi & $45,275,904.28$ & - & - & $45,275,904.28$ \\
\hline 22 & Kogi & $33,632,106.66$ & - & - & $33,632,106.66$ \\
\hline 23 & Kwara & $51,032,662.69$ & - & - & $51,032,662.69$ \\
\hline 24 & Lagos & $1,101,400,597.65$ & $106,500,000.00$ & - & $1,207,900,597.65$ \\
\hline 25 & Nassarawa & $53,066,146.92$ & - & - & $53,066,146.92$ \\
\hline 26 & Niger & $38,280,717.63$ & $6,500,000.00$ & - & $44,780,717.63$ \\
\hline 27 & Ogun & $103,331,349.94$ & - & - & $103,331,349.94$ \\
\hline 28 & Ondo & $52,089,561.21$ & - & - & $52,089,561.21$ \\
\hline 29 & Osun & $69,946,131.15$ & $6,950,000.00$ & - & $76,896,131.15$ \\
\hline 30 & Oyo & $66,754,604.54$ & - & - & $66,754,604.54$ \\
\hline 31 & Plateau & $30,474,421.99$ & - & - & $30,474,421.99$ \\
\hline 32 & Rivers & $46,992,403.74$ & - & - & $46,992,403.74$ \\
\hline 33 & Sokoto & $41,946,527.11$ & - & - & $41,946,527.11$ \\
\hline 34 & Taraba & $22,943,478.17$ & - & - & $22,943,478.17$ \\
\hline 35 & Yobe & $30,456,120.37$ & - & - & $30,456,120.37$ \\
\hline 36 & Zamfara & $34,919,653.15$ & - & - & $34,919,653.15$ \\
\hline \multirow[t]{2}{*}{37} & FCT & $35,044,755.92$ & - & - & $35,044,755.92$ \\
\hline & Sub-total & $3,216,961,154.54$ & $152,950,000.00$ & - & $3,369,911,154.54$ \\
\hline \multirow[t]{2}{*}{38} & FGN & $4,343,471,023.88$ & $5,000,000.00$ & $3,000,049,316.38$ & $7, \mathbf{3 4 8 , 5 2 0 , 3 4 0 . 2 6}$ \\
\hline & Total & $7,560,432,178.42$ & $157,950,000.00$ & $3,000,049,316.38$ & $10,718,431,494.80$ \\
\hline
\end{tabular}

Source: Debt Management Office (http://www.dmo.gov.ng/)

The fundamental issues thus include the question of what the central and state governments have done with these borrowings. The origin of Nigeria's external debt was dated back to 1958 when a sum of US\$28 million was used to finance the Nigeria Railway Corporation [10]. Five 
decades after, has the Nigerian Railway become satisfactorily functional? The truth is that Nigerian citizens cannot easily relate public debt to national progress. Funds that are obtained through public debts are not easily associated with commonly identifiable projects that survive for the benefit of the masses. And civil servants (bureaucrats) are usually there at the implementation stages of these assumed projects.

Table 2: Federal Government of Nigeria's Domestic Debt Stock by Instruments as at December 31, 2015 (Amounts in Naira)

\begin{tabular}{|l|c|c|}
\hline Instruments & Amount & Percentage \\
\hline Federal government bonds & $5,808,140,821,000$ & 65.72 \\
\hline Nigerian treasury bills & $2,772,867,038,000$ & 31.38 \\
\hline Treasury bonds & $255,988,000,000$ & 2.90 \\
\hline Total & $8,836,995,859,000$ & 100.00 \\
\hline
\end{tabular}

Source: Debt Management Office, Nigeria (http://www.dmo.gov.ng/)

Table 2 above is a specific presentation of the domestic debt stock of the Federal Government of Nigeria as at December 31, 2015. It stands at N8.83trillion. How have the borrowed resources been utilized? As indeed, a persistent aspect of the public debt conundrum in Nigeria borders on what Sanusi [19] perceives as how to ensure that borrowed resources are productively utilized, such that economic and social rate of return is higher than the future servicing cost. Then for the past two decades, Egbetunde [20] argues, Nigeria has borrowed large amounts of funds, often at highly concessional interest rates with the hope to put the country on a faster route to development through further investments, accelerated growth processes and poverty reduction but on the contrast, economic retardation and poverty situations are staggering at the back door of the country. This scenario is undeniably detrimental to sustainable national development. Inflation, hunger, starvation, corruption, unbridled consumerism and unrestrained importation of consumer goods into the country, have accordingly remained the negative sides of the national developmental process.

Table 3: Nigeria's Public Debt Stock as at December 31, 2015 (In millions)

\begin{tabular}{|l|l|c|c|}
\hline \multicolumn{2}{|c|}{ Debt Category } & $\begin{array}{c}\text { Amount Outstanding } \\
\text { in USD }\end{array}$ & $\begin{array}{c}\text { Amount Outstanding } \\
\text { in NGN }\end{array}$ \\
\hline \multirow{2}{*}{ A. } & External Debt Stock ( FGN+States) & $10,718.43$ & $2,111,530.71$ \\
\cline { 2 - 4 } & Domestic Debt Stock (FGN Only) & $44,857.85$ & $8,836,995.86$ \\
\cline { 2 - 4 } & Sub-Total & $55,576.28$ & $10,948,526.57$ \\
\hline B. & Domestic Debt of States & $9,852.25$ & $1,655,178.71$ \\
\hline C. & Grand-Total (A+B) & $65,428.53$ & $12,603,705.28$ \\
\hline
\end{tabular}

Source: Debt Management Office (http://www.dmo.gov.ng/)

In the above, table (table 3 ) the actual domestic debt stock for the 36 states of the country and the Federal Capital Territory (FCT) were as at December 2014. The Central Bank of Nigeria's official exchange rate of 1USD to 197 NGN as at December 31, 2015 and 168 NGN as at December 2014 were used in respect of the Federal Government's and States' domestic debts respectively [21]. In other words, if the figures for the domestic debt of states were updated, they would have recorded higher values.

The debt structure of a country, argues Emmanuel [22] affects individual citizens, institutions of government, privately owned corporate organizations like banks and consequently the economy at large. The debt structure in this context is the magnitude of the domestic debt as well as the magnitude of the external debts [22]. It is argued in this study that the bureaucracy is a guilty party in the perfidies that lead to impaired growth and poverty situations in the country, despite the 
various governments' huge debt structures. According to Bhatia [12], in certain respects, government borrowings resemble the private ones. Thus, like a private borrower, the government may also borrow either for consumption or for investment purposes. And it will also be paying interest on such borrowings.

It appears therefore as if in the Nigerian case, government borrowing is largely for the financing of consumption. Bureaucrats and politicians have accordingly transmuted the public debt scenario in Nigeria to a bazaar situation, as the national debt profile is not easily relatable to sustainable development. The debts may merely be incurred for the purposes of building the most modern and most complex sports stadium in Africa or for the consumptive purposes of augmenting the shortfalls in monthly salaries and other overheads.

It is argued in this study that to begin to borrow on monthly bases [4] to keep the national bureaucracy in office would further, certainly affect negatively, sustainable national development in Nigeria. It raises the question of what the bureaucracy contributes to sustainable national development in a public-debt endemic country. Furthermore, it raises a morally thorny issue of why the burden of debts incurred in one generation to maintain a national workforce, in other words, pay the salaries of workers in one generation, may be borne by future generations (of citizens).

In the course of this study, Governor Ayo Fayose of Nigeria's Ekiti state wrote to the Chinese Government, requesting the authorities in that country to stop any new loans to the Federal Government of Nigeria [23]. Mr Fayose may not possess the locus standi to achieve much in writing such a letter. However, his arguments include the fact that servicing Nigeria's current debt burden, already gulps over 25 per cent of the country's annual budget and that if the future of Nigeria must be protected, the country does not currently need further foreign debts. These are certainly fundamental issues but how would Mr. Fayose also stop the composite state governments in Nigeria, as reflected in tables 1 and 3 above (including his own Ekiti State, when he leaves office) from accessing such foreign facilities? Nigeria's Governor Fayose's position however remains relevant to the sustainable national development trajectory of this study.

\section{Conclusion and Recommendations}

There has indeed, been a very weak linkage between public debt and sustainable national development in Nigeria. This study has attempted to highlight the incidence of this weakness. It has also highlighted that the expertise in the Nigerian bureaucracy has not positively related with public debt and sustainable national development in the country. The paper accordingly recommends in sustainable development paradigms, that less emphasis be placed on public debts in the country, as the current national public debt narrative has truly not led to specifically desirable destinations. In place of public debt in perpetuity therefore, the study recommends taxation-increases as alternative to public debt, in ensuring that current generations do not endanger the capacity of future generations to meet their own needs.

\section{References}

[1] C.D. Checherita, P. Rother, The impact of high and growing government debt on economic growth: an empirical investigation for the euro area, European Central Bank, Frankfurt am Main, 2000.

[2] Y.B. Raman, et al., Debt management and economic growth in Nigeria: performance, challenges and responsibilities, Manager Journal. 12(1) (2010) 31-39.

[3] F.I. O. Izedonmi, O.J. Ilaboya, Public debt-growth dynamics: The Nigerian experience, Journal of Research in National Development. 10(3) (2012) 252-260.

[4] M. Pam, FG borrows N600 billion monthly to pay salaries, New Telegraph, Wednesday, April 13, 2016, p. 2. 
[5] T. Chukwunyem, A. Emmanuel, China offers Nigeria \$6billion loan for infrastructure development, New Telegraph, April 13, 2016, p.1.

[6] Information on http://www.tradingeconomics.com/nigeria/external-debt.

[7] E.M.C. Izueke, Some theoretical frameworks of analysis in public administration, in: O.M Ikeanyibe, P. Mbah (Eds.), An anthology of theories for social research, University of Nigeria Press, Nsukka, Nigeria, 2014.

[8] M. Celik, E. Dogan, A theoretical approach to the science of management, International Journal of Humanities and Social Science. 1(3) (2011) 65-69.

[9] Information on http://www.ozyazilim.com/ozgur/marmara/orgut/burokrasi.html.

[10] W.K Adebayo, J.K. Olowookere, Managing Nigerian debt: The practical solutions, Research Journal of Finance and Accounting. 4(19) (2013) 116-123.

[11] C.O. Udoka, S. Ogege, Public debt and the crisis of development in Nigeria: Econometric Investigation, Asian Journal of Finance and Accounting. 4(2) (2012) 231-243.

[12] H.L. Bhatia, Public Finance, Twenty sixth edition, Vikas Publishing House, New Delhi, 2008.

[13] F. Modigliani, Long-run implications of alternative fiscal policies and the burden of the national debt, Economic Journal. 71(284) (1961) 730-755.

[14] P. Krugman, Financing vs. forgiving a debt overhang: Some analytical issues, NBER Working Paper No. 2486, 1988.

[15] R. Emas, The concept of sustainable development: Definition and defining principles, Brief for Global Sustainable Development Report (GSDR), 2015.

[16] United Nations General Assembly, Report of the world commission on environment and development: Our common future, United Nations General Assembly, Development and International Co-operation: Environment, Oslo, Norway, 1987.

[17] N. Kutay, F.A. Tektüfekçi, New era for sustainable development: A comparison for sustainability indices, Journal of Accounting, Finance and Auditing Studies, 2(2) (2016) 7095.

[18] J.R. Siche et al., Sustainability of nations by indices: Comparative study between environmental sustainability index, ecological footprint and the emergy performance indices, Ecological economics. 66(4) (2008) 628- 637.

[19] J.O. Sanusi, Management of Nigeria's domestic debt. Keynote address by Dr Joseph O Sanusi, Governor of the Central Bank of Nigeria, at the 7th Monetary Policy Forum organized by the Central Bank of Nigeria at the CBN Conference Hall, Abuja, 22 May, 2003.

[20] T. Egbetunde, Public debt and economic growth in Nigeria: Evidence from granger causality, American Journal of Economics. 2(6) (2012) 101-106.

[21] Information on http://www.dmo.gov.ng/.

[22] O.O. Emmanuel, An empirical analysis of the impact of public debt on economic growth: evidence from Nigeria, 1975-2005, Canadian Social Science. 8(4) (2012) 154-161.

[23] Information on http:/www.premiumtimesng.com/news/more-news/201814-fayose-writeschinese-government-stop-nigerias-loan-request.html. 